the aforementioned authors. Upon analysing it, we are able to prove the fact that the general cultural symbols connect different cultures, as it was stated in the comparative analysis of the poems «Open Windows» by Sara Teasdale and «Давня весна» by Lesya Ukrainka.

\title{
References:
}

1. Коробко Л. В. Літературознавчі поняття в інтертексті культури. Слово $i$ Час. Київ : Інститут літератури ім. Т. Г. Шевченка НАН України, 2009. Вип. 12. С. 86-94.

2. Леся Українка. Вибрані твори : у 4-х томах. / упор. Н. Вишневська. Київ : Дніпро, 1981. Т. 1. 541 с.

3. Паньков А. І., Мейзерська Т. С. Поетичні візії Лесі Українки: онтологія змісту і форми : монографія. Одеса : Астропринт, 1996. 76 с.

4. Потапенко О. Словник символів. / під заг. ред.. О. Потапенка, М. Дмитренка. Київ : Народознавство, 1997. 156 с.

5. Teasdale S. Flame and Shadow. URL : http://www.theotherpages.org/ poems/books/teasdale/flame01.html.

6. Teasdale S. Rivers to the Sea. URL : http://www.theotherpages.org/ poems/books/teasdale/rivers01.html.

DOI https://doi.org/10.30525/978-9934-26-039-1-64

\section{ГУЦУЛЬЩИНА КАСТАНА АБГАРОВИЧА ТА ЮРІЯ ФЕДЬКОВИЧА: ГЕНДЕРНИЙ АСПЕКТ}

\author{
Микитин І. Я. \\ кандидат філологічних наук, \\ дочент кафедри мовознавства \\ Івано-Франківського начіонального медичного університету \\ м. Івано-Франківськ, Украӥна
}

Питання гендерного співіснування у площині культурного пограниччя - проблема маловивчена та актуальна в сучасному літературознавчому дискурсі, оскільки репрезентує подвійний вияв периферійності - буття на межі і водночас в ситуації патріархальної гендерної опозиції фемінного до маскулінного. Простором культурного пограниччя виступає й Гуцульщина Каєтана Абгаровича та Юрія Федьковича, представлена у прозовій творчості польського та українського письменників обширним топосом, багатим на конотації та приховані смисли, 
окремий вияв якого втілюють образи карпатських мешканців - не тільки чоловіків-нащадків опришків, але й жінок-гуцулок з чітким знаком «іншого».

Для Каєтана Абгаровича край Карпатських гір належав до так званих «кресових» земель - втрачених східних теренів Першої Речі Посполитої. Відповідно, польський письменник вірменського походження, знаний в польській літературі кінця XIX - початку XX ст. під псевдонімом АбгарСолтан, сприймав гірський простір як своєрідний «крес кресів» - кінець «свого» світу і початок «іншого», а горян змальовував як екзотичних «напівдиких дітей гір», нестримний характер яких $є$ продовженням суворої та грізної карпатської природи. Тому невипадково жінка-гуцулка у текстах на гуцульську тематику Каєтана Абгаровича виказує як трансцендентну, так і демонічну сутність, приваблює та водночас лякає, все ж в «чоловічому» письмі автора є своєрідним доповненням патріархально облаштованого світу чоловіків.

У творах польського автора періодично з'являються і зникають жіночі постаті, що 3 власної волі є жертвами спокусників-гуцулів, наприклад, образ Аніки Дудякової з оповідання «Ілько Шваб’юк», молодиці Катерини - коханки гуцула Миколи 3 оповідання «При мисливському вогнищі», численні безіменні жіночі постаті, про яких згадує автор, обрамлюючи картину домінування маскулінного новими любовними звершеннями. Підтвердженням цьому служить розповідь гуцула-наратора оповідання «При мисливському вогнищі»: «Як я мав сімнадцять років, вже знав всіх дівчат і молодиць вздовж цілої ріки, від Ясенева аж по Буркут; і вони мене знали, і голубили, і в очі мені говорили, що кращого легіня на цілі гори нема; я платив їм за це гарячими поцілунками, ніжними обіймами, шовковими хустками $\mathrm{i}$ криваво-червоним намистом, які купував за батьківські дукати у Вижниці, в Кутах або аж в угорському Сигеті» [4, с. 229]. Взаємне зближення статей у пошуках «ідеалу» чуттєвої насолоди зумовлювало ситуацію своєрідного самоствердження маскулінного i фемінного гендерних світів. Така модель сприйняття жінок чоловічою статтю у прозі польського письменника нагадувала сформульовану С. де Бовуар концепцію, згідно якої жінка є чимось іншим, «за допомогою якого він [чоловік. - М. I.] пізнає самого себе» [1, с. 71]. У випадку Абгаровичевого змалювання гуцульського виміру співіснування статей ситуація була прямо протилежною: саме чоловіки у перцепції жінок стали тим «іншим», існування якого підтверджувало неповторність власної жіночої індивідуальності. 
Незважаючи на модус вільних стосунків (стереотип розгульного життя гуцулів» (як чоловіків, так і жінок), що присутній у польській свідомості другої половини XIX ст. [5; 6]), оприявнений Каєтаном Абгаровичем у постаті молодого гуцула Миколи, наратор подає діаметрально протилежні погляди батьків на розпусний спосіб життя головного персонажа оповідання «При мисливському вогнищі» Миколи: «Мати плакала, свої білі господарські руки ламала, говорила, що я молоду душу гублю, смертельний гріх на неї беру; батько сміявся з цього і казав, що молодому треба вишумітися доки подорослішає і одруженим господарем стане» [4, с. 229]. Якщо батько позитивно оцінює шалений успіх сина у жінок, пояснюючи потребу такого типу поведінки у становленні серйозного господаря, то мати засмучена розгульним життям дитини, вчинки якої суперечать християнським нормам, що співвідносить окреслену жіночу постать 3 образом люблячої неньки, яка вболіває за щасливу долю своїх дітей з оповідань Юрія Федьковича «Люба-згуба», «Серце не навчити», «Стефан Славич», «Три як рідні брати», «Безталанне закохання», «Побратим», «Дністрові кручі» тощо.

«Чоловічий» i «жіночий» погляди на розпусний спосіб життя молодого гуцула Миколи у художній інтерпретації Каєтана Абгаровича протилежні, проте уособлюють грані перетину світоглядних парадигм язичництва (модель полігамії) і християнства (модель моногамії). Якщо образи молодих жінок близькі до біблійного образу прародительки Сви (мотив гріхопадіння, присутній, зокрема, у художній постаті Маріки 3 оповідання «Ілько Шваб'юк» та численних безіменних жіночих постатях), то змалювання матерів, як у художній інтерпретації Юрія Федьковича, виявляють типологічні паралелі 3 образом Богородиці (постать матері Маріки - старої Мартинихи 3 оповідання «Ілько Шваб’юк», матері гуцула Миколи 3 оповідання «При мисливському вогнищі», матері Ілька Шваб'юка 3 однойменного твору), що змальовуються епізодично, проте ілюструють безмірну любов до власної дитини, терплячість і покору перед світом маскулінного.

Гуцульщина Юрія Федьковича - його «мала батьківщина». Карпатський простір та гірські мешканці, представлені в прозі відомого українського письменника XIX ст., $\epsilon$ художнім віддзеркаленням світу автора «зсередини» - трансцендентного, в якому немає місця на змалювання тілесного. На відміну від Абгара-Солтана, який відкрито позиціонує гіпертрофований вимір еротизму i чуттєвості у житті чоловічої та жіночої статей, Юрій Федькович уникає таких тем, проте все ж по-своєму, з перспективи моралі, торкається питання позашлюбних відносин та завуальовує проблему легковажного ставлення до кохання в 
образі Сидора $з$ оповідання «Побратим». Гуцул уособлює романтичний тип донжуанівського спокусника, що шукає «ідеал» - таку дівчину, яка б «[...] ся не дала парубкові на підмову» [2, с. 78]. Образ персонажа Юрія Федьковича типологічно співвідноситься з художньою постаттю Миколи-персонажа оповідання Каєтана Абгаровича «При мисливському вогнищі», проте якщо польський письменник показує загальноприйняту, тому й неосудну в гуцульському суспільстві модель вільних відносин 3 вектором до полігамії, то український письменник сигналізує про неприйнятність окресленої поведінки. У художній інтерпретації Юрія Федьковича приреченість гуцульського спокусника не викликає сумніву: альтернатива вбивства від руки друга або власне самогубство однаково стане смертною карою за скоєне. Така ситуація є символічним виявом авторського осуду гуцульського втілення донжуанівської тілесності, що у патріархальному світі християнізованої Гуцульщини відомого українського літератора виявляється неприпустимим.

\section{Література:}

1. Бовуар Сімона де. Друга стать: у 2-х т. Київ: Основи, 1994. T. $1.390 \mathrm{c}$.

2. Федькович Ю. Твори : в 2 т. Київ: Дніпро, 1984. Т. 2. 426 с.

3. Abgar-Sołtan. Ilko Szwabiuk. Abgar-Sołtan. Ilko Szwabiuk. Dobra nauczka. Lwów : Jakubowski i Zadurowicz, 1896. S. 1-141.

4. Abgar-Sołtan. Przy ognisku myśliwskiem. Abgar-Sołtan. Rusini. Szkice $i$ obrazki. Kraków : Nakładem Księgarni Spółki Wydawniczej Polskiej, 1893. S. 213-280.

5. Radziszewska J. XIX - wieczne wyobrażenie Huculszczyzny. Huculszczyzna: kultura $i$ edukacja / pod red. A. Haratyk. Torun : Wydawnictwo A. Marszałek, 2009. S. 80-90.

6. Radziszewska J. Obraz Huculszczyzny w XIX-wiecznych relacjach podróżniczych. Wrocławskie Studia Wschodnie. 2001. №5. S. 97-111. 